\title{
Paenibacillus (Formerly Bacillus) gordonae (Pichinoty et al. 1986) Ash et al. 1994 Is a Later Subjective Synonym of Paenibacillus (Formerly Bacillus) validus (Nakamura 1984) Ash et al. 1994: Emended Description of $P$. validus
}

\author{
M. HEYNDRICKX,${ }^{1} \mathrm{~K}$. VANDEMEULEBROECKE, ${ }^{1}$ P. SCHELDEMAN,${ }^{1}$ B. HOSTE,${ }^{1} \mathrm{~K}$. KERSTERS, ${ }^{1}$ \\ P. DE VOS, ${ }^{1 *}$ N. A. LOGAN, ${ }^{2}$ A. M. AZIZ, ${ }^{2}$ N. ALI, ${ }^{3}$ AND R. C. W. BERKELEY ${ }^{3}$ \\ Laboratorium voor Microbiologie, Universiteit Gent, B-9000 Ghent, Belgium, and Department of Biological Sciences, \\ Glasgow Caledonian University, Glasgow G4 OBA, ${ }^{2}$ and Department of Pathology \& Microbiology, \\ School of Medical Sciences, Bristol BS8 1TD, ${ }^{3}$ United Kingdom
}

\begin{abstract}
A polyphasic study in which we performed an amplified ribosomal DNA restriction analysis, sodium dodecyl sulfate-polyacrylamide gel electrophoresis of whole-cell proteins, a gas chromatographic analysis of methylated fatty acids, pyrolysis mass spectrometry, a random amplified polymorphic DNA analysis, a phenotypic analysis, and an analysis of the levels of DNA binding of Paenibacillus gordonae and Paenibacillus validus strains (including both type strains) showed that these organisms form a homogeneous group and that the names $P$. gordonae and $P$. validus are therefore synonyms. $P$. validus has nomenclatural priority, and an emended description of this species is given; the type strain is strain LMG 11161 (= ATCC 43897).
\end{abstract}

In 1992 the International Committee on Systematic Bacteriology Subcommittee on the Taxonomy of the Genus Bacillus (15) decided to undertake a collaborative polyphasic taxonomic study of the genus Bacillus, with a view toward establishing minimal standards for the description of species and revising the nomenclature of the group, starting with mesophilic and psychrophilic species which form sporangia swollen by ellipsoidal spores. In the following year, Ash et al. (2) proposed that several members of this group should be reclassified in the new genus Paenibacillus. Recently, this name was validated (validation list no. 51). This new genus contains Paenibacillus gordonae (formerly Bacillus gordonae) and Paenibacillus validus (formerly Bacillus validus). These species are the subject of this study. Ash et al. (2) found a level of sequence similarity of $99.8 \%$ between the ribosomal DNAs (rDNAs) of the type strains of $P$. gordonae and $P$. validus.

In 1935 Bredemann and Heigener (3) described the species B. validus. Later, Smith et al. (30) and Gordon et al. (10) reclassified $B$. validus strains as Bacillus circulans strains, and as the former species was considered to be inadequately described, it was not included on the Approved Lists of Bacterial Names (29). Nakamura and Swezey (24) found that the guanine-plus-cytosine $(\mathrm{G}+\mathrm{C})$ content of the DNA of their $B$. validus strain was 54 mol\%, and they considered this organism to be unrelated to $B$. circulans sensu stricto strains, whose DNA $\mathrm{G}+\mathrm{C}$ contents ranged from 37 to $39 \mathrm{~mol} \%$. On the basis of the results of new phenotypic and genotypic (DNA-DNA homology) studies, Nakamura (23) revived the name B. validus for the same group of organisms to which it was originally applied.

Pichinoty et al. (25) isolated 30 endospore-forming strains from pasteurized soil samples by aerobic enrichment in minimal media containing various aromatic compounds. These authors considered their isolates members of morphological group 2 of Smith et al. (30), as these organisms produced

\footnotetext{
* Corresponding author. Mailing address: Universiteit Gent, Vakgroep BFM WE10V, Laboratorium voor Microbiologie, K.L. Ledeganckstraat, 35, B-9000 Ghent, Belgium. Phone: 32 (0)9 264 5110. Fax: 32 (0)9 264 5346. Electronic mail address: Paul.Devos@rug.ac.be.
}

sporangia which were swollen by ellipsoidal spores. Pichinoty et al. (25) believed that their strains represented a new species (B. gordonae) because they were aerobic (unlike most other group 2 strains, which are facultatively anaerobic) and found that they could be clearly differentiated from the two other aerobic members of the group, Bacillus brevis and Bacillus azotoformans. The reported $\mathrm{G}+\mathrm{C}$ content of this new Bacillus species was $55 \pm 0.6 \mathrm{~mol} \%$ (25).

Our restriction analysis of enzymatically amplified $16 \mathrm{~S}$ rDNAs from $P$. validus and $P$. gordonae revealed that all 14 strains studied produced similar patterns, and this was considered a strong indication that these organisms are very closely related phylogenetically. These strains were further examined in a polyphasic study to determine the exact taxonomic and nomenclatural implications at the species level.

\section{MATERIALS AND METHODS}

For all of the methods used in this study many strains were tested at least twice. In this paper we describe only individual observations, unless indicated otherwise.

Strains used. The designation of each strain which we studied, its origin, its taxonomic status, and the different methods that we used to study it are shown in Table 1. All strains were checked for purity by plating on nutrient agar ( $\mathrm{pH}$ 7.4) and microscopic examination. The strains were maintained at $4^{\circ} \mathrm{C}$ on slopes of nutrient agar containing $5 \mathrm{mg}$ of $\mathrm{MnSO}_{4} \cdot 4 \mathrm{H}_{2} \mathrm{O}$ per liter to enhance sporulation and as lyophilized cultures.

SDS-PAGE of whole-cell proteins. To obtain material for sodium dodecyl sulfate (SDS)-polyacrylamide gel electrophoresis (PAGE), cells were grown in petri dishes on nutrient agar supplemented with $1 \%(\mathrm{wt} / \mathrm{vol})$ glucose $(\mathrm{pH} 7.4)$ for $24 \mathrm{~h}$. We used previously described methods to prepare and electrophorese SDS protein extracts (27). The protein profiles were recorded densitometrically, stored as normalized data in a PC-AT computer, and analyzed numerically with the GelCompar software (Applied Maths, Kortrijk, Belgium) by using the Pearson product moment correlation coefficient. A cluster analysis was performed by the unweighted pair group method using arithmetic averages (UPGMA) clustering technique (32).

Gas chromatographic analysis of methylated fatty acids. Cells were grown on Trypticase soy agar containing $3.0 \%$ (wt/vol) Trypticase soy broth (BBL) and $1.5 \%$ (wt/vol) Bacto Agar (Difco) at $28^{\circ} \mathrm{C}$ for $24 \mathrm{~h}$. Approximately $60 \mathrm{mg}$ (wet weight) of cells was harvested from each plate from the most diluted quadrant exhibiting confluent growth. We used previously described methods for fatty acid extraction, methyl ester preparation, and methyl ester separation by gas chromatography (33). The fatty acid methyl ester profiles were identified with the Microbial Identification System software (MIS version 3.8; Microbial ID, Inc., 
TABLE 1. Designations and sources of the Paenibacillus strains used and methods used to study them

\begin{tabular}{|c|c|c|c|c|c|c|c|c|c|}
\hline \multirow[b]{2}{*}{ Strain or species ${ }^{a}$} & \multirow[b]{2}{*}{ Other designation(s) ${ }^{a}$} & \multirow[b]{2}{*}{ Source $^{a}$} & \multicolumn{7}{|c|}{ Methods used } \\
\hline & & & ARDRA & $\begin{array}{l}\text { API } \\
\text { tests }^{b}\end{array}$ & PAGE & $\begin{array}{l}\text { FAME } \\
\text { analysis }^{c}\end{array}$ & $\begin{array}{c}\text { DNA } \\
\text { homology }\end{array}$ & Py-MS & $\begin{array}{l}\text { RAPD } \\
\text { analysis }\end{array}$ \\
\hline P. validus LMG $11161^{\mathrm{T}}$ & $\mathrm{B} 1397^{\mathrm{T}}$, DSM $3037^{\mathrm{T}}$ & DSM & + & + & + & + & + & + & + \\
\hline P. validus LMG 14018 & B1392, NRRL NRS-838A & Nakamura & $\mathrm{NR}^{d}$ & + & NR & NR & NR & + & + \\
\hline P. validus LMG 14019 & B1393, NRRL NRS-839A & Nakamura & + & + & + & + & + & + & + \\
\hline P. validus LMG 14020 & B1394, NRRL NRS-625 & Nakamura & + & + & + & + & + & + & + \\
\hline P. gordonae $\mathrm{LMG} 9817^{\mathrm{T}}$ & B1395 ${ }^{\mathrm{T}}$, Pichinoty Q $1^{\mathrm{T}}$, ATCC $29948^{\mathrm{T}}$ & ATCC & + & + & + & + & + & + & + \\
\hline P. gordonae LMG 14717 & B1399, Pichinoty Q 2 & Pichinoty & + & NR & + & + & NR & NR & NR \\
\hline P. gordonae LMG 14663 & B1400, Pichinoty Q 3 & Pichinoty & + & + & + & + & NR & + & + \\
\hline P. gordonae LMG 14664 & B1401, Pichinoty Q 12 & Pichinoty & + & + & + & + & NR & + & + \\
\hline P. gordonae LMG 14665 & B1402, Pichinoty Ipht 1 & Pichinoty & + & + & + & + & NR & + & + \\
\hline P. gordonae LMG 14666 & B1403, Pichinoty Pohb 1 & Pichinoty & + & + & + & + & + & + & + \\
\hline P. gordonae LMG 14667 & B1404, Pichinoty Pohb 3 & Pichinoty & + & + & + & + & + & + & + \\
\hline P. gordonae LMG 14668 & B1405, Pichinoty Tri 5 & Pichinoty & + & + & + & + & + & + & + \\
\hline P. gordonae LMG 14468 & Pichinoty Q 13, DSM 6390 & DSM & + & NR & + & + & NR & NR & NR \\
\hline P. gordonae LMG 14469 & Pichinoty Pohb 3, DSM 6544 & DSM & + & NR & + & + & NR & NR & NR \\
\hline P. gordonae LMG 14470 & Pichinoty Tri 4, DSM 6545 & DSM & + & NR & + & + & NR & NR & NR \\
\hline P. pulvifaciens LMG 13302 & B0302, T. Gibson 1301 & Gibson & NR & NR & NR & NR & NR & + & NR \\
\hline P. pulvifaciens LMG 13303 & B0307, T. Gibson 11.1301 & Gibson & NR & NR & NR & NR & NR & + & NR \\
\hline P. peoriae & B1412, NRRL NRS 1312 & Nakamura & NR & NR & NR & NR & NR & + & NR \\
\hline P. peoriae LMG 14672 & B1413, NRRL NRS 14475 & Nakamura & NR & NR & NR & NR & NR & + & NR \\
\hline P. polymyxa LMG $6319^{\mathrm{T}}$ & DSM $36^{\mathrm{T}}$, ATCC $842^{\mathrm{T}}$ & DSM & + & NR & + & NR & NR & NR & NR \\
\hline P. polymyxa LMG 13296 & B0264, T. Gibson 43 & Gibson & NR & NR & + & NR & NR & NR & NR \\
\hline P. larvae LMG $9820^{\circ}$ & ATCC $9545^{\mathrm{T}}$ & ATCC & NR & NR & + & NR & + & NR & NR \\
\hline P. larvae LMG 14425 & ATCC 25747 & ATCC & NR & NR & + & NR & NR & NR & NR \\
\hline P. larvae LMG 14426 & ATCC 25748 & ATCC & NR & NR & + & NR & + & NR & NR \\
\hline P. macquariensis LMG $6935^{\mathrm{T}}$ & DSM $2^{\mathrm{T}}$, ATCC $23464^{\mathrm{T}}$ & DSM & + & NR & NR & NR & NR & NR & NR \\
\hline
\end{tabular}

${ }^{a}$ ATCC, American Type Culture Collection, Rockville, Md.; B, N. A. Logan Bacillus Collection, Glasgow Caledonian University, Glasgow, United Kingdom; DSM, Deutsche Sammlung von Mikroorganismen, Braunschweig, Germany; T. Gibson, T. Gibson collection, University of Bristol, Bristol, United Kingdom; LMG, Laboratorium voor Microbiologie Collection, Universiteit Gent, Ghent, Belgium; Nakamura, L. K. Nakamura, U.S. Department of Agriculture, Peoria, Ill.; NRRL, Northern Regional Research Laboratory Collection, Peoria, Ill.; NRS, N. R. Smith Collection; Pichinoty, F. Pichinoty, UER Scientifique de Luminy, Marseille, France.

${ }^{b}$ API System tests and morphological observations.

c FAME, fatty acid methyl ester.

${ }^{d} \mathrm{NR}$, not reported.

Newark, Del.) and were clustered by using the statistical program CLUS (Microbial ID, Inc.)

Py-MS. Cells were grown on nutrient agar for 24 to $36 \mathrm{~h}$ at $30^{\circ} \mathrm{C}$. Bacterial sample preparation and pyrolysis mass spectrometry (Py-MS) of the samples were performed as described previously (9). Three samples of each strain were analyzed. The raw data were first normalized with the resident PYSTAT program (13), and this was followed by a principal-component analysis to reduce the data for a canonical variates analysis, both by the GENSTAT program (13), which produced a generalized distance matrix. This matrix was transformed to a similarity level matrix by using the general similarity coefficient of Gower (11) to make the data amenable to a UPGMA analysis.

Phenotypic characterization and numerical analysis. Strains were characterized by the methods of Logan and Berkeley (18) by using the following API tests and other phenotypic tests and observations: 16 biochemical tests (gas production from carbohydrates, casein digestion, growth and hemolysis on horse blood agar, and 12 of the API $20 \mathrm{E}$ strip tests) and 49 carbohydrate tests in API $50 \mathrm{CH}$ galleries (using the API CHB suspension medium), nine growth temperature tests (with temperatures ranging from 4 to $55^{\circ} \mathrm{C}$ ), and 12 characteristics determined by phase-contrast microscopy, including motility, vegetative cell curvature shape of the cell ends, chain formation, the presence of spores, spore shape (ellipsoidal, cylindrical, or spherical) and position (central and paracentral, subterminal, or terminal), and swelling of the sporangia. The results of biochemical tests were scored on a scale of 0 (negative) to 5 (strongly positive); and the result of growth temperature tests and microscopic observations were scored as 0 (absent or negative) or 1 (present or positive). The data were subjected to a numerical taxonomic analysis by using the GENSTAT 5 program. Levels of similarity, with negative matches in the API tests both ignored and included, were calculated by using the similarity coefficient of Gower, and the results were examined by performing an UPGMA analysis. Anaerobic growth at $30^{\circ} \mathrm{C}$ was tested for in tubes containing thioglycolate medium (Brewer) (Oxoid) and tubes containing the anaerobic agar of Gordon et al. (10) as described by Claus and Berkeley (4), with growth at the medium-air interfaces acting as aerobic controls in both cases, as well as in nutrient agar containing $1 \%$ (wt/vol) glucose and incubated anaerobically (anaerobic system BR 38; Oxoid) in parallel with aerobic control plates containing the same medium. Results were recorded after 2,5 , and 7 days.

DNA preparation. For DNA-DNA binding experiments (see below), DNA was extracted from 5 to $10 \mathrm{~g}$ (wet weight) of cells grown in Roux flasks containing 130 $\mathrm{ml}$ of nutrient agar for $48 \mathrm{~h}$ at $30^{\circ} \mathrm{C}$ by using a slight modification of the method of Marmur (21), as described previously (36). For the amplified rDNA restriction analysis (ARDRA) (see below), total genomic DNA was purified by a method slightly modified from the method of Pitcher et al. (26); cells grown in petri dishes containing nutrient agar for 24 to $48 \mathrm{~h}$ at $30^{\circ} \mathrm{C}$ were lysed in an additional step by incubating them with lysozyme at a final concentration of $50 \mathrm{mg} / \mathrm{ml}$ of TE buffer $(10 \mathrm{mM}$ Tris-HCl, $1 \mathrm{mM}$ EDTA; $\mathrm{pH} 8.0)$ for $30 \mathrm{~min}$ at $37^{\circ} \mathrm{C}$. After the DNA was purified, it was treated with RNase at a final concentration of 250 $\mu \mathrm{g} / \mathrm{ml}$ of TE buffer for $1 \mathrm{~h}$ at $37^{\circ} \mathrm{C}$. The quality of the purified DNA was monitored by $1 \%(\mathrm{wt} / \mathrm{vol})$ agarose gel electrophoresis, and the amount of DNA was determined on the basis of the $A_{260}$.

Levels of DNA-DNA binding. DNAs from representative strains of each species were used to determine the levels of DNA-DNA binding (expressed as percentages) spectrophotometrically by using the initial renaturation method of De Ley et al. (7), as described previously (35).

DNA base composition. The mean $\mathrm{G}+\mathrm{C}$ contents were determined by the thermal denaturation method (8) and were calculated by using the equation of Marmur and Doty (22) as modified by De Ley (6).

ARDRA. Enzymatically amplified 16S rDNA was obtained by performing a PCR in $50 \mu$ l of PCR buffer (10 mM Tris- $\mathrm{HCl}[\mathrm{pH} 8.4], 1.5 \mathrm{mM} \mathrm{MgCl} 2,50 \mathrm{mM}$ $\mathrm{KCl}$ ) containing $10 \mathrm{nmol}$ of each deoxynucleoside triphosphate (Pharmacia Biotech Benelux, Roosendaal, The Netherlands), $20 \mathrm{pmol}$ of each primer (forward primer $5^{\prime}$-AGTTTGATCCTGGCTCAG-3' and reverse primer $5^{\prime}$-TACCTTGT TACGACTTACCCCA-3'; Escherichia coli nucleotide positions 10 to 27 and 1507 to 1485, respectively; Pharmacia Biotech Benelux), $1.25 \mathrm{U}$ of EuroTaq DNA polymerase (Eurogentec, Seraing, Belgium), and $250 \mathrm{ng}$ of template DNA. A Perkin-Elmer model 9600 thermocycler was used with the following program: an initial denaturation step at $95^{\circ} \mathrm{C}$ for $5 \mathrm{~min}$ was followed by 40 cycles consisting of denaturation at $95^{\circ} \mathrm{C}$ for $30 \mathrm{~s}$, annealing at $55^{\circ} \mathrm{C}$ for $30 \mathrm{~s}$, and extension at $72^{\circ} \mathrm{C}$ for $1 \mathrm{~min}$ and a final extension step at $72^{\circ} \mathrm{C}$ for $10 \mathrm{~min}$. The presence and yield of the specific PCR product (length, about $1,500 \mathrm{bp}$ ) were monitored by $1 \%$ (wt/vol) agarose gel electrophoresis. Restriction digestion of the amplified 16S rDNA was carried out for $2 \mathrm{~h}$ at $37^{\circ} \mathrm{C}$ in $20-\mu \mathrm{l}$ reaction mixtures containing $10 \mu \mathrm{l}$ of the PCR product solution, $2 \mu \mathrm{l}$ of a commercially supplied incubation buffer, and $5 \mathrm{U}$ of one of the following restriction enzymes: HaeIII (Boehringer, Mannheim, Germany), RsaI (Pharmacia Biotech Benelux), DpnII (New England Bio- 


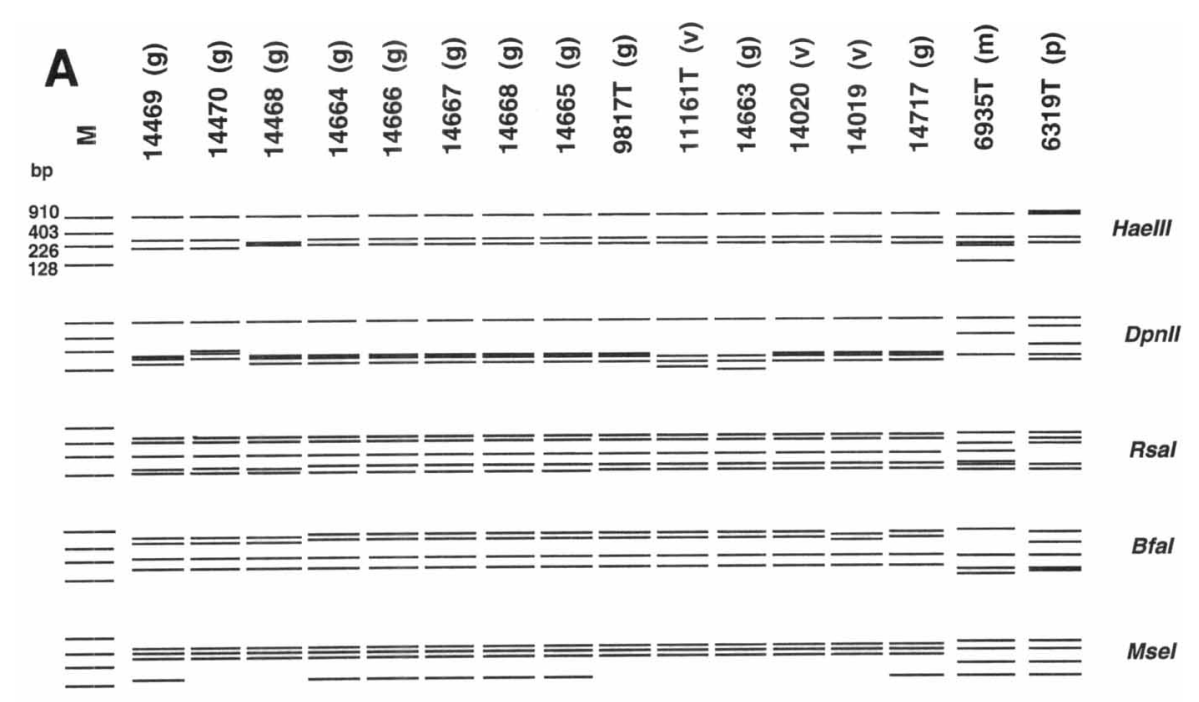

B

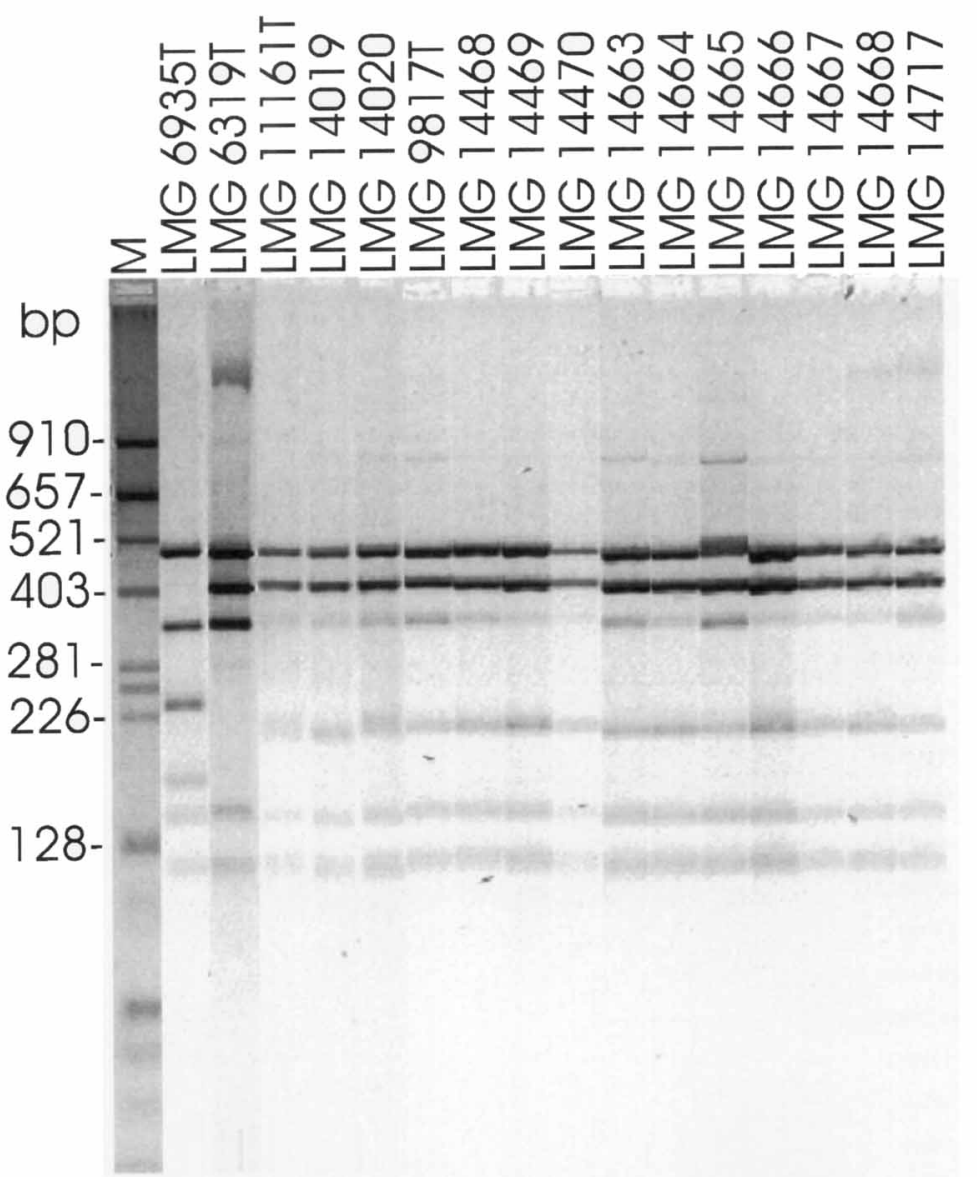

FIG. 1. (A) Schematic representation of normalized composite 16S rDNA restriction profiles from an ARDRA of $P$. gordonae (g), $P$. validus (v), $P$. polymyxa (p), and $P$. macquariensis (m) strains obtained with restriction enzymes HaeIII. DpnII, RsaI. BfaI, and MseI. Lane M contained a molecular weight marker. (B) Normalized computer profiles of the RsaI restriction patterns of the $16 \mathrm{~S}$ rDNAs of $P$. gordonae LMG 9817 ${ }^{\mathrm{T}}$. LMG 14468, LMG 14469, LMG 14470, LMG 14663, LMG 14664, LMG 14665, LMG 14666, LMG 14667, LMG 14668, and LMG 14717, P. validus LMG 11161 ${ }^{\mathrm{T}}$, LMG 14019, and LMG 14020, P. polymyxa LMG 6319 ${ }^{\mathrm{T}}$, and $P$. macquariensis LMG $6935^{\mathrm{T}}$ (strains LMG $6319^{\mathrm{T}}$ and LMG $6935^{\mathrm{T}}$ were used as outgroup organisms). Lane M contained a molecular weight marker.

labs), $B f a \mathrm{I}$ (New England Biolabs), or Msel (New England Biolabs). After $4 \mu \mathrm{l}$ of sample buffer ( $4 \mathrm{~g}$ of sucrose and $2.5 \mathrm{mg}$ of bromophenol blue in $10 \mathrm{ml}$ of TE buffer) was added, $20-\mu$ l portions of the restriction digests were analyzed by $2 \%$ (wt/vol) Metaphor agarose (FMC BioProducts, Rockland, Maine) gel electrophoresis at $3 \mathrm{~V} / \mathrm{cm}$ for $130 \mathrm{~min}$ in $89 \mathrm{mM}$ Tris- $89 \mathrm{mM}$ boric acid-2 mM EDTA (TBE) buffer ( $\mathrm{pH} 8.0$ ) containing $0.5 \mu \mathrm{g}$ of ethidium bromide per ml. After an additional 20 min of staining with $1 \mu \mathrm{g}$ of ethidium bromide per $\mathrm{ml}$ in TBE buffer and 5 min of destaining with distilled water, the gels were photographed under UV illumination by using Polaroid type 665 positive/negative film. The negatives were scanned with a ScanJet IIp scanner (Hewlett-Packard) for normalization of the restriction patterns with the GelCompar software by using the profile of plasmid pBR322 digested with $A l u \mathrm{I}$ (Pharmacia Biotech Benelux) as a reference 


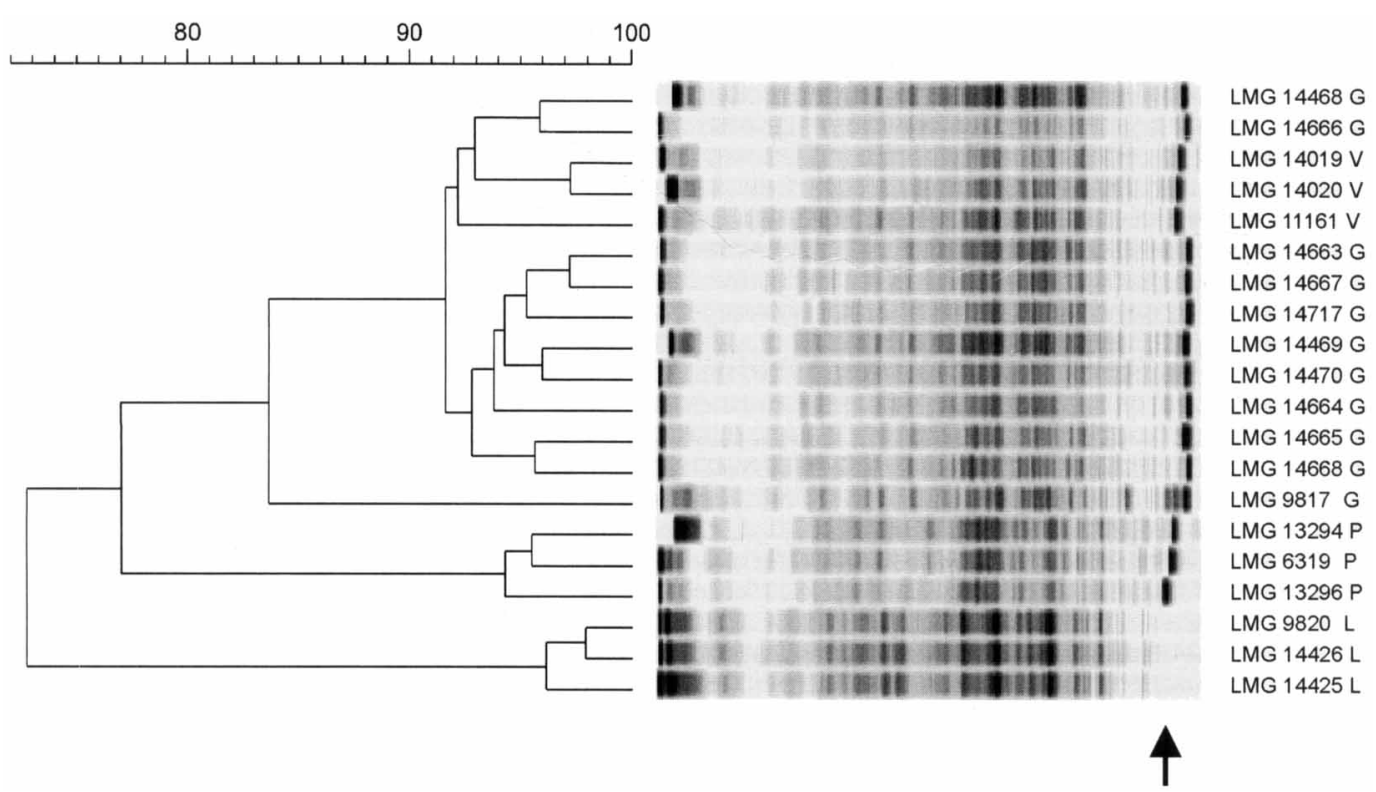

FIG. 2. Normalized computer profiles of PAGE protein patterns of $P$. gordonae and $P$. validus strains. The scale on the upper left indicates percent similarity. $P$. polymyx $a$ and $P$. larvae were used as outgroup organisms. The irregular high-molecular-weight bands to the right of the arrow were omitted from the numerical analysis presented in a dendrogram based on the UPGMA linkage of correlation coefficients. Abbreviations: G, $P$. gordonae; V, P. validus; $\mathrm{P}, P$. polymyxa; L, P. larvae.

profile. The five normalized restriction patterns obtained for each strain were assembled into a composite profile and analyzed by using the Dice similarity coefficient and the UPGMA clustering algorithm. Bands whose intensities were definitely lower than the intensities of immediately adjacent bands (probably because of microheterogeneity in the $16 \mathrm{~S}$ rRNA alleles) were not included in this numerical analysis.

RAPD analysis. Random amplified polymorphic DNA (RAPD) analysis PCR were carried out with whole-cell lysates by using a single arbitrary primer. Approximately $5 \mu \mathrm{g}$ of cells was obtained from colonies grown on nutrient agar for 24 to $36 \mathrm{~h}$ at $30^{\circ} \mathrm{C}$. After the cells were suspended in $15 \mu \mathrm{l}$ of sterile distilled water, the preparation was boiled for 4 to $8 \mathrm{~min}$ and centrifuged for $20 \mathrm{~s}$ at 10,000 $\times g$. Then $10 \mu$ l of the resulting supernatant was added to $50 \mu l$ of a PCR mixture containing $1 \times$ Super Taq reaction buffer $(10 \mathrm{mM}$ Tris- $\mathrm{HCl}[\mathrm{pH} 9.0], 50 \mathrm{mM} \mathrm{KCl}$, $0.01 \%$ [wt/vol] gelatin, $1.5 \mathrm{mM} \mathrm{MgCl}_{2}, 0.1 \%$ Triton X-100), $10 \mathrm{nmol}$ of each deoxynucleoside triphosphate (Pharmacia Biotech, St. Albans, United Kingdom), $1.5 \mathrm{U}$ of Super Taq DNA polymerase (HT Biotechnology, Cambridge, United Kingdom), and $25 \mathrm{pmol}$ of primer 42423 (5'-GGGCGTTGTCGGTGT TCATG-3'; Department of Biochemistry, University of Bristol, Bristol, United Kingdom) (20). The PCR were carried out with an OmniGene temperature cycler (model CM 220; Hybaid, Ltd., Teddington, United Kingdom) by using the following program: initial denaturation at $94^{\circ} \mathrm{C}$ for 3 min was followed by four cycles of intermediate product formation consisting of denaturation at $94^{\circ} \mathrm{C}$ for

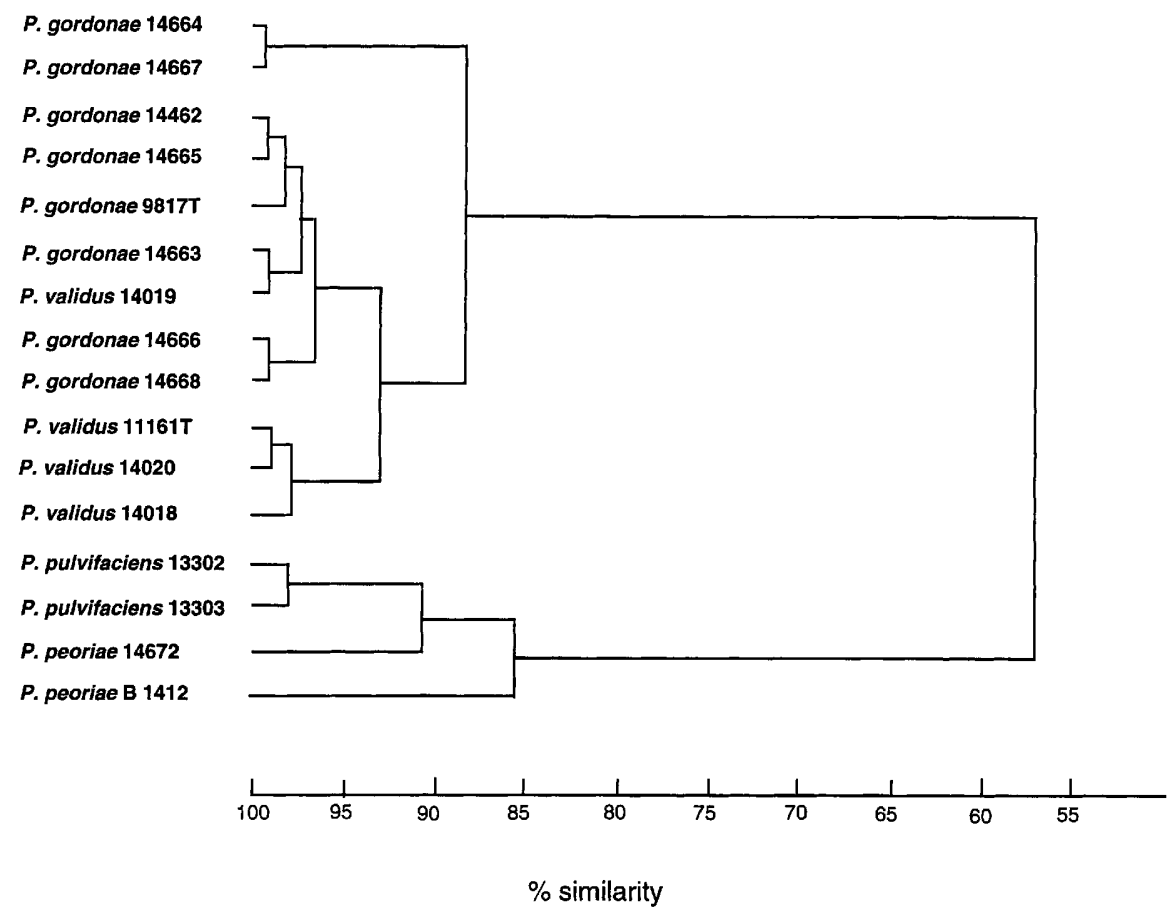

FIG. 3. Dendrogram based on UPGMA linkage of Gower correlation coefficients for Py-MS data for $P$. gordonae, $P$. validus, $P$. pulvifaciens, and $P$. peoriae strains. 
$45 \mathrm{~s}$, annealing at $26^{\circ} \mathrm{C}$ for $2 \mathrm{~min}$, and extension at $72^{\circ} \mathrm{C}$ for $2 \mathrm{~min}$, and then the main amplification step $\left(30\right.$ cycles consisting of $94^{\circ} \mathrm{C}$ for $45 \mathrm{~s}, 36^{\circ} \mathrm{C}$ for $1 \mathrm{~min}$, and $72^{\circ} \mathrm{C}$ for $2 \mathrm{~min}$ ) was followed by the final extension step at $72^{\circ} \mathrm{C}$ for $5 \mathrm{~min}$. A $20-\mu l$ portion of the PCR products and a 1-kb DNA ladder (Gibco BRL) which was used as a molecular weight marker were analyzed by $1 \%$ (wt/vol) agarose gel electrophoresis in TBE buffer containing $0.5 \mu \mathrm{g}$ of ethidium bromide per $\mathrm{ml}$ at $100 \mathrm{~V}$ for 1.5 to $3 \mathrm{~h}$. The band patterns were photographed under UV illumination with Polaroid type 677 positive-image film. The photos were scanned with a ScanJet IIp scanner (Hewlett-Packard), and the scanned images were analyzed with the Gelmanager program (Biosystematica, Tavistock, United Kingdom) by using the Pearson product moment correlation coefficient and the UPGMA clustering algorithm.

Nucleotide sequence accession number. The $16 \mathrm{~S}$ rDNA sequence of strain DSM $3037^{\mathrm{T}}$ ( $\mathrm{T}=$ type strain) has been deposited in the EMBL data library under accession number M77489.

\section{RESULTS AND DISCUSSION}

ARDRA. Bands whose intensities were definitely lower than the intensities of adjacent bands appeared in some restriction patterns (for example, the band at about $340 \mathrm{bp}$ in the $P$. gordonae and $P$. validus patterns in Fig. 1B). These less pronounced bands were probably caused by additional restriction sites in a minority of the $16 \mathrm{~S}$ rRNA alleles $(12,31)$. In a numerical analysis (data not shown) of the ARDRA patterns of Bacillus rRNA group 3 (1) strains, we found that all of the $P$. gordonae and $P$. validus strains clustered at levels of similarity of more than $86 \%$ and that the type strains of the two taxa were linked at a level of similarity of $95 \%$. The amplified $16 \mathrm{~S}$ rDNA restriction patterns of all $11 P$. gordonae strains examined and the $3 P$. validus strains examined (Fig. 1A and B) exhibited high levels of internal similarity compared with the patterns of two outgroup organisms, Paenibacillus polymyxa and Paenibacillus macquariensis.

Although with all methods that rely on multivariate analysis levels of similarity may vary with the kind and number of strains included, our ARDRA data strongly indicate that $P$. gordonae and $P$. validus should be united at the species level. The high level of rDNA restriction pattern similarity is supported by a high level of rDNA sequence similarity $(99.8 \%)$ between the $P$. gordonae and $P$. validus type strains (2). Finally, restriction analysis of enzymatically amplified rDNAs, as applied in this study, has been used previously to delineate species $(12,14,17,28,31)$.

In order to confirm the phylogenetic homogeneity indicated by the rDNA data, the strains were also examined in a polyphasic study in which we performed SDS-PAGE of whole-cell proteins, a gas chromatographic analysis of methylated fatty acids, a Py-MS analysis, a RAPD analysis, a biochemical and morphological analysis, and DNA-DNA binding studies.

SDS-PAGE. The PAGE (Fig. 2) data revealed that all of the $P$. gordonae and $P$. validus strains clustered at a similarity level of about $75 \%$ (data not shown). This rather low level of similarity was due to the irregular pattern of one or two dense protein bands in a zone at the top of the gel. It has been shown previously that the characteristics of such zones often mask the real levels of similarity between overall profiles (5). If the data for this zone (all bands with molecular weights of more than $1.4 \times 10^{5}$ in the protein profile) (Fig. 2) were not included in the numerical analysis, all of the $P$. gordonae and $P$. validus strains except $P$. gordonae LMG $9817^{\mathrm{T}}$ clustered at levels of similarity of more than $90 \%$, and $P$. gordonae $\mathrm{LMG} 9817^{\mathrm{T}}$ was linked at a level of similarity of $84 \%$. The latter value is still very high and definitely more than the levels of linkage to the nearest neighbors, $P$. polymyxa and Paenibacillus larvae (Fig. 2 ). Therefore, these results support the results based on rDNA data.

Fatty acid methyl esters. The fatty acid compositions of all strains (Table 2) were very similar. A comparison of the mean 


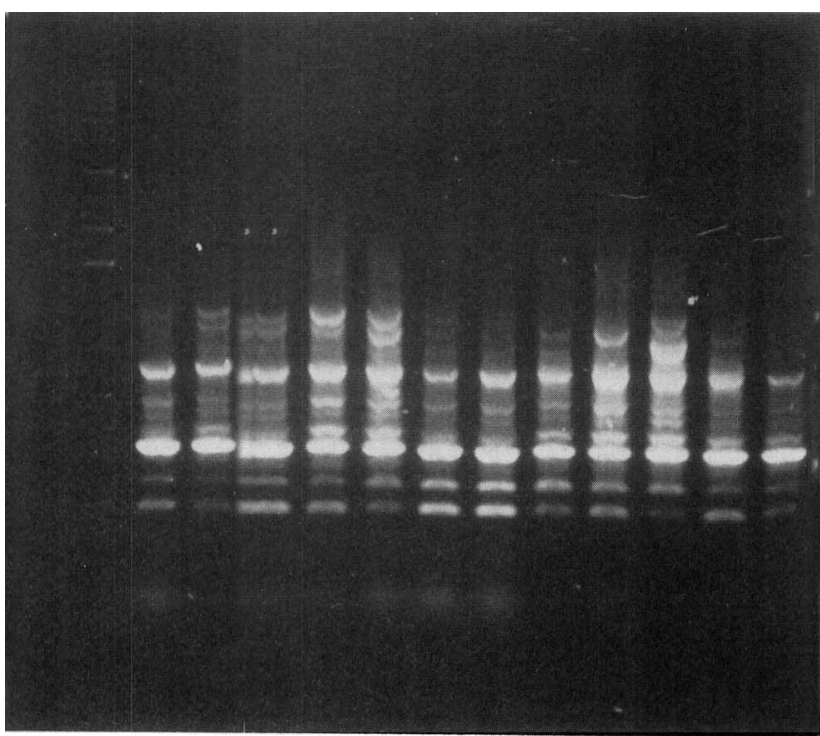

$\frac{1, \frac{2}{2} 3,4,5,6, \frac{7,8,9,10,11,12,13}{P \text { validus }}}{P \text { gordonae }}$

FIG. 4. RAPD patterns of $P$. gordonae and $P$. validus strains obtained with primer 42423. Lane 1 contained the 1 -kb molecular weight ladder; lanes 2 to 5 contained $P$. validus LMG 14018, LMG 14019, LMG 14020, and LMG $11161^{\mathrm{T}}$, respectively; and lanes 6 to 13 contained $P$. gordonae LMG 9817 ${ }^{\mathrm{T}}$, LMG 14717, LMG 14663 , LMG 14664, LMG 14665, LMG 14666, LMG 14667, and LMG 14668, respectively.

compositions of the different strains of each taxon revealed that the qualitative patterns were the same and that there were only minor quantitative differences, as indicated by the minimum and maximum levels of each fatty acid. Furthermore, in a numerical analysis (data not shown) all of the strains clustered below a Euclidian distance of 5, which confirmed that this group of strains was homogeneous and supported the hypothesis that these organisms are members of a single species.

Py-MS. The dendrogram in Fig. 3 shows the results of a numerical analysis of the Py-MS data for eight strains of $P$. gordonae, four strains of $P$. validus, two strains of Paenibacillus pulvifaciens, and two strains of Paenibacillus peoriae (members of the latter two species were used as outgroups). All of the $P$. gordonae and $P$. validus strains clustered at high levels of similarity (range, 89 to $99.4 \%$ ), while the level of similarity between the type strains was $92 \%$. Similarly, the two-dimensional canonical variates analysis plots of the first and second vectors and the first and third vectors in the Py-MS analysis (data not shown) clearly revealed the close affinities of the members of the two species, as indicated by the overlapping confidence limits around group means determined by using the chi-square procedure $(16,19)$

RAPD patterns. The band patterns obtained in the RAPD PCR analysis of $P$. gordonae and $P$. validus strains were very similar (Fig. 4). When we performed a numerical analysis of the PCR data, the strains formed two mixed clusters linked at similarity levels of more than $90 \%$. Within one of the clusters the type strains were linked at a similarity level of $97 \%$.

Biochemical, physiological, and morphological characteristics. In our numerical analysis of API data and morphological observations, the $P$. validus and $P$. gordonae strains were recovered in one diffuse cluster with levels of similarity ranging from 67.5 to $95 \%$ when negative matches in API data were ignored and from 80 to $97.5 \%$ when negative matches were included. Some of the levels of similarity between strains assigned to the two different species were greater than the levels

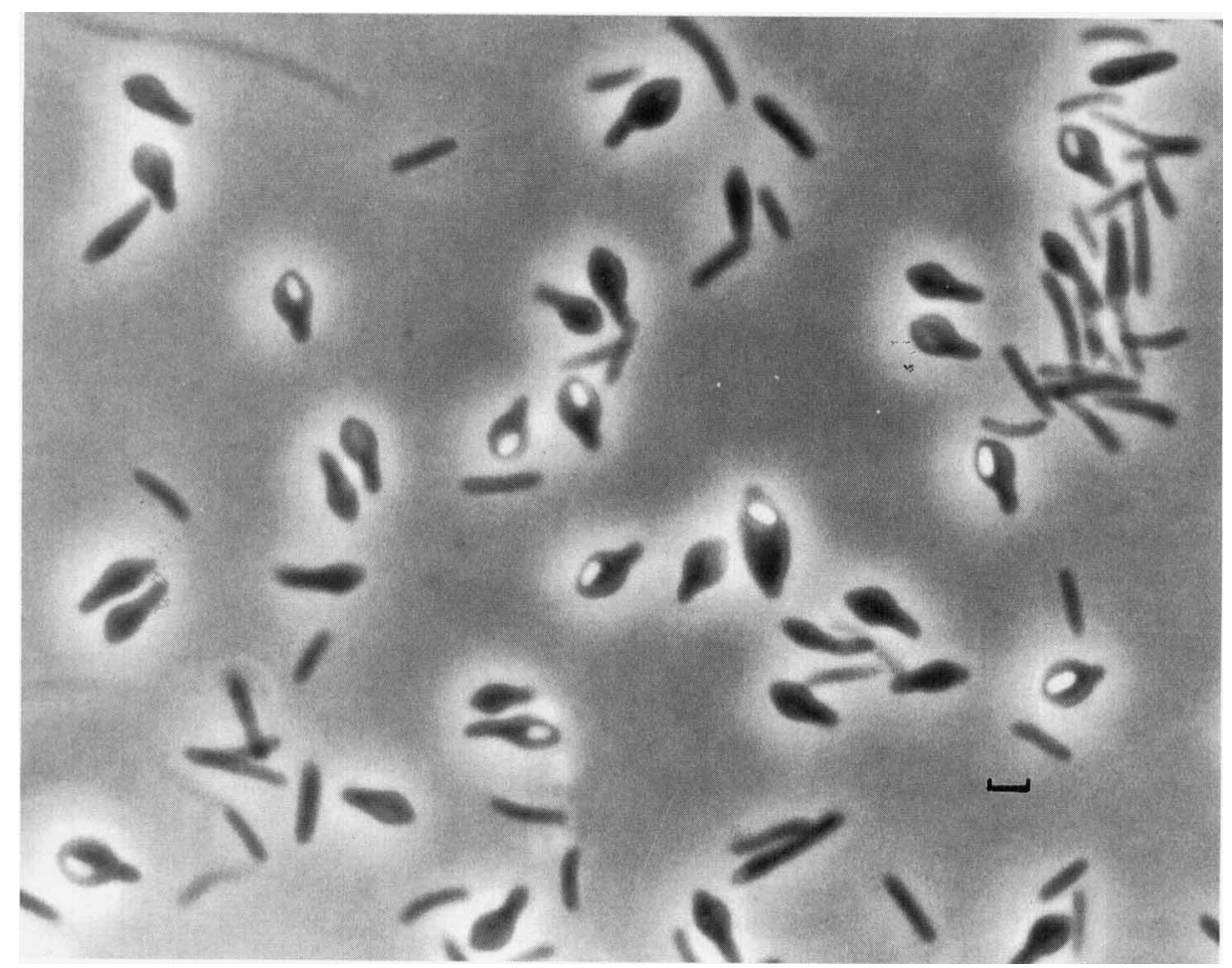

FIG. 5. Photomicrograph of sporangia and vegetative cells of $P$. validus LMG $11161^{\mathrm{T}}$ viewed by phase-contrast microscopy. The sporangia are irregular in shape and greatly swollen with subterminal to terminal ellipsoidal spores. Bar $=2 \mu \mathrm{m}$. 
TABLE 3. Phenotypic characteristics of $P$. validus and $P$. gordonae strains

\begin{tabular}{|c|c|c|}
\hline Characteristic $^{a}$ & P. validus & P. gordonae \\
\hline Motility & $t^{b}$ & + \\
\hline Ellipsoidal spores & + & + \\
\hline Subterminal spores & + & + \\
\hline Swollen sporangia & + & + \\
\hline Esculin hydrolysis & + & + \\
\hline Anaerobic growth & - & - \\
\hline Arginine dihydrolase activity & - & - \\
\hline Citrate utilization & - & - \\
\hline Indole production & - & - \\
\hline Gelatin liquefaction & - & - \\
\hline Nitrate reduction & $\mathrm{v}$ & $\mathrm{v}$ \\
\hline ONPG hydrolysis $^{c}$ & - & - \\
\hline Voges-Proskauer reaction & $\mathrm{v}$ & $\mathrm{v}$ \\
\hline \multicolumn{3}{|l|}{ Acid produced from ${ }^{d}$ : } \\
\hline $\begin{array}{l}\text { D-Fructose, galactose, D-glucose, } \\
\text { glycerol, meso-inositol, maltose, } \\
\text { mannitol, methyl-D-glucoside, ribose, } \\
\text { sucrose, D-trehalose, D-turanose, and } \\
\text { D-xylose }\end{array}$ & + & + \\
\hline $\begin{array}{l}\text { Glycogen, D-mannose, D-melibiose, } \\
\text { D-raffinose, and starch }\end{array}$ & $\mathrm{v}$ & $\mathrm{v}$ \\
\hline D-Arabitol & - & $\mathrm{v}$ \\
\hline D-Cellobiose & - & $\mathrm{v}$ \\
\hline Dulcitol & $\mathrm{v}$ & + \\
\hline Inulin & - & $\mathrm{v}$ \\
\hline Lactose & - & $\mathrm{v}$ \\
\hline D-Sorbitol & - & $\mathrm{v}$ \\
\hline Xylitol & - & $\mathrm{v}$ \\
\hline
\end{tabular}

${ }^{a}$ All characteristics except anaerobic growth and microscopic properties were determined by using API 20E and API 50 CHB System tests; anaerobic growth was tested for as described in the text.

$b+, 90 \%$ or more of the strains react positively;,$- 90 \%$ or more of the strains react negatively; $v$, less than $90 \%$ of the strains react positively or negatively for this characteristic.

${ }^{c}$ ONPG, $o$-nitrophenyl- $\beta$-D-galactopyranoside.

${ }^{d}$ Acid was not produced from adonitol, amygdalin, D- and L-arabinose, Larabitol, arbutin, erythritol, D- and L-fucose, gentiobiose, gluconate, 2-keto-D-gluconate, 5-keto-D-gluconate, D-lyxose, D-melezitose, methyl-D-mannoside, methylxyloside, $N$-acetylglucosamine, L-rhamnose, salicin, L-sorbose, and L-xylose.

of similarity between strains assigned to the same species. Although the type strains of the two species could be distinguished by API tests, overall the two species exhibited similar patterns of reactions (Table 3), had similar microscopic morphologies (Fig. 5), and could be distinguished from related Paenibacillus species (Table 4). None of the strains exhibited anaerobic growth with any of the three methods used to test this characteristic. Thus, in our hands $P$. gordonae and $P$. vali$d u s$ behaved as strict aerobes.

DNA-DNA binding studies. A level of DNA binding (Table 5 ) of $89 \%$ between the type strains of $P$. gordonae and $P$. validus and levels of binding of at least 89 and $92 \%$ within the $P$. gordonae group and the $P$. validus group, respectively, confirmed that all of the strains of these two taxa should be assigned to the same species (34).

Conclusion. When Smith et al. (30) and Gordon et al. (10) reclassified $B$. validus as $B$. circulans, they recognized the marked heterogeneity of the latter species, but found that division of the group was impossible as the many combinations of variant properties did not allow recognition of discrete groups, and they wished to emphasize the similarities of their strains rather than the differences between them. Nakamura and Swezey (24) considered B. validus unrelated to B. circulans sensu stricto on the basis of the different $\mathrm{G}+\mathrm{C}$ contents of the DNAs of these taxa. Nakamura (23) revived the name $B . v a$ -
TABLE 4. Characteristics that differentiate $P$. validus from related Paenibacillus species

\begin{tabular}{|c|c|c|c|c|}
\hline Characteristic $^{\alpha}$ & P. validus & P. alvei & P. larvae & P. pulvifaciens \\
\hline Anaerobic growth & - & + & + & + \\
\hline $\begin{array}{l}\text { Arginine dihydrolase } \\
\text { activity }\end{array}$ & - & - & - & + \\
\hline Indole production & - & + & - & - \\
\hline Gelatin liquefaction & - & + & + & + \\
\hline ONPG hydrolysis ${ }^{b}$ & - & + & - & - \\
\hline \multicolumn{5}{|l|}{ Acid produced from: } \\
\hline D-Xylose & + & - & - & - \\
\hline Adonitol & - & + & - & - \\
\hline D-Fructose & + & - & - & - \\
\hline Mannitol & + & - & - & + \\
\hline$N$-Acetylglucosamine & - & + & + & + \\
\hline Maltose & + & + & - & - \\
\hline
\end{tabular}

${ }^{a}$ All characteristics except anaerobic growth were determined by using API $20 \mathrm{E}$ and API $50 \mathrm{CHB}$ System tests; $P$. validus strains were tested for anaerobic growth as described in the text, and data for other species were obtained from references 4 and 10 .

${ }^{b}$ ONPG, $o$-nitrophenyl- $\beta$-D-galactopyranoside.

lidus on the basis of DNA-DNA homology data and found a pattern of phenotypic characteristics which correlated with the characteristics of the $B$. validus DNA relatedness group. In our polyphasic analysis, we were not able to separate the strains classified by Pichinoty et al. as $B$. gordonae (25) and the $B$. validus strains by using morphological and biochemical characteristics and a range of chemotaxonomic and genomic characteristics. We concluded that the name $P$. gordonae is a synonym of $P$. validus, and an emended description of $P$. validus based on our data and on data from Pichinoty et al. (25), Nakamura (23), and Ash et al. (2) is given below.

Emended description of Paenibacillus validus. Paenibacillus validus (va'li.dus. L. adj. validus, strong, vigorous). Motile, round-ended rods that are 0.5 to $1.0 \mu \mathrm{m}$ wide by 5.0 to $7.0 \mu \mathrm{m}$ long occur singly and in pairs. Sporangia are irregular in shape and often greatly swollen by subterminal to terminal ellipsoidal spores which may lie laterally and/or at an angle in the swollen part and which may sometimes be in the unswollen part of the sporangium.

Isolated from soil. Strictly aerobic and catalase positive. The organism grows on routine media such as nutrient agar, producing greyish white, translucent, smooth, circular, entire colonies that are 1 to $2 \mathrm{~mm}$ in diameter after 3 days at $30^{\circ} \mathrm{C}$; colonies on nutrient agar have a loose butyrous consistency and become tenacious with age. The optimum growth temperature range is 28 to $35^{\circ} \mathrm{C}$, the maximum temperature is 42 to $50^{\circ} \mathrm{C}$, and the minimum temperature is 5 to $10^{\circ} \mathrm{C}$.

Gelatin and $o$-nitrophenyl- $\beta$-D-galactopyranoside are not hydrolyzed, citrate is not utilized, and arginine dihydrolase, hydrogen sulfide, urease, and indole are not produced as determined by API 20E strip tests; weak Voges-Proskauer and nitrate reduction reactions are detected in some strains.

In API CH 50 galleries when API CHB suspension medium is used, acid is produced from the following substrates: Dfructose, D-galactose, D-glucose, glycerol, meso-inositol, maltose, D-mannitol, methyl-D-glucoside, ribose, sucrose, D-trehalose, D-turanose, and D-xylose. Acid is not produced from adonitol, amygdalin, D- and L-arabinose, L-arabitol, arbutin, erythritol, D- and L-fucose, gentiobiose, D-gluconate, 2-keto-Dgluconate, 5-keto-D-gluconate, D-lyxose, D-melezitose, methylD-mannoside, methyl-D-xyloside, $N$-acetylglucosamine, L-rhamnose, salicin, L-sorbose, and L-xylose. Different strains give different results with D-cellobiose, dulcitol, glycogen, inulin, 
TABLE 5. G $+\mathrm{C}$ contents of and DNA binding data for Paenibacillus strains

\begin{tabular}{|c|c|c|c|c|c|c|c|c|c|c|}
\hline \multirow[b]{2}{*}{ Strain } & \multirow[b]{2}{*}{$\begin{array}{c}\mathrm{G}+\mathrm{C} \text { content } \\
(\mathrm{mol} \%)\end{array}$} & \multicolumn{3}{|c|}{3} & \multicolumn{3}{|c|}{$\%$ DNA binding ${ }^{a}$} & \multirow[b]{2}{*}{ 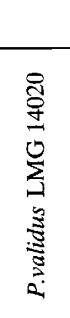 } & \multirow[b]{2}{*}{ 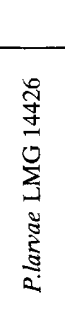 } & \multirow[b]{2}{*}{ 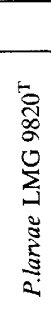 } \\
\hline & & 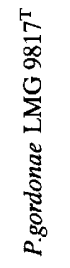 & 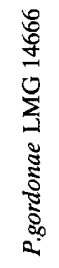 & 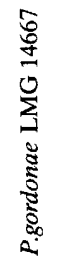 & 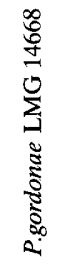 & 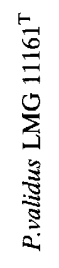 & 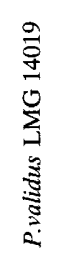 & & & \\
\hline P. gordonae $\mathrm{LMG} 9817^{\mathrm{T}}$ & 52.3 & 100 & & & & & & & & \\
\hline P. gordonae LMG 14666 & & 94 & 100 & & & & & & & \\
\hline P. gordonae LMG 14667 & & 94 & 97 & 100 & & & & & & \\
\hline P. gordonae LMG 14668 & & 89 & & 96 & 100 & & & & & \\
\hline P. validus LMG $11161^{\mathrm{T}}$ & 50.9 & 89 & & & & 100 & & & & \\
\hline P. validus LMG 14019 & & & & & & 96 & 100 & & & \\
\hline P. validus LMG 14020 & & & & & & & 92 & 100 & & \\
\hline P. larvae LMG 14426 & 42.2 & & 17 & & & & & & 100 & \\
\hline P. larvae LMG $9820^{\mathrm{T}}$ & 42.3 & & & & & & 4 & & & 100 \\
\hline
\end{tabular}

${ }^{a}$ Data are the means of the values from at least two experiments. The $P$. larvae strains were used as outgroup organisms.

lactose, D-mannose, D-arabitol, D-melibiose, D-raffinose, D-sorbitol, starch, and xylitol.

The following fatty acids are present: 14:0 iso, 14:0, 15:0 iso, 15:0 anteiso, 16:1 $\omega 7 \mathrm{C}, 16: 0$ iso, 16:1 $\omega 11,16: 0,17: 0$ iso, and 17:0 anteiso.

The average $\mathrm{G}+\mathrm{C}$ content is 51 to $52 \mathrm{~mol} \%$ (as determined by the renaturation method) or 54 to $55 \mathrm{~mol} \%$ (as determined by the buoyant density method). The level of internal DNA relatedness of the strains is more than 70\%. ARDRA tests in which HaeIII, RsaI, DpnII, BfaI, and $M s e I$ are used produce similar patterns. See Materials and Methods for $16 \mathrm{~S}$ rDNA sequence data.

The type strain is strain LMG 11161 (= ATCC $43897=$ B1397 = DSM 3037 = NRRL NRS-1000), and this strain has the characteristics of the species described above. This strain is positive for the Voges-Proskauer test, nitrate reduction, and acid production from glycogen, D-mannose, D-melibiose, D-raffinose, and starch and negative for acid production from D-cellobiose, dulcitol, inulin, lactose, D-sorbitol, and xylitol.

\section{ACKNOWLEDGMENTS}

We thank L. K. Nakamura and F. Pichinoty for providing cultures of $B$. validus and $B$. gordonae.

P.D.V. and M.H. are indebted to the National Fund for Scientific Research (Belgium) for a position as a Senior Research Associate and a position as a Senior Research Assistant, respectively, and N.A. is indebted to the University of Kuwait. K.K. acknowledges the Fund for Medical Scientific Research (Belgium) for personnel and research grants.

\section{REFERENCES}

1. Ash, C., J. A. E. Farrow, S. Wallbanks, and M. D. Collins. 1991. Phylogenetic heterogeneity of the genus Bacillus revealed by comparative analysis of small-subunit-ribosomal RNA sequences. Lett. Appl. Microbiol. 13:202206.

2. Ash, C., F. G. Priest, and M. D. Collins. 1993. Molecular identification of rRNA group 3 bacilli (Ash, Farrow, Wallbanks and Collins) using a PCR probe test. Antonie Leeuwenhoek 64:253-260.

3. Bredemann, G., and H. Heigener. 1935. Bacillus validus Bredemann and Heigener. Zentralbl. Bakteriol. Parasitenkd. Infektionskr. Hyg. Abt. 2 93:97-98.

4. Claus, D., and R. C. W. Berkeley. 1986. Genus Bacillus Cohn 1872, p: 1105-1139. In P. H. A. Sneath, N. S. Mair, M. E. Sharpe, and J. G. Holt (ed.), Bergey's manual of systematic bacteriology, vol. 2. The Williams \& Wilkins Co., Baltimore.

5. Costas, M. 1992. Classification, identification, and typing of bacteria by the analysis of their one-dimentional polyacrylamide gel electrophoretic protein patterns, p. 351-408. In A. Chambrach, M. J. Dunn, and B. J. Radola (ed.), Advances in electrophoresis, vol. 5. VCH Verlagsgesellschaft, Weinheim, Germany.

6. De Ley, J. 1970. Reexamination of the association between melting point, buoyant density and chemical base composition of deoxyribonucleic acid. J. Bacteriol. 101:738-754.

7. De Ley, J., H. Cattoir, and A. Reynaerts. 1970. The quantitative measurement of DNA hybridization from renaturation rates. Eur. J. Biochem. 12: 133-142.

8. De Ley, J., and J. Van Muylem. 1963. Some applications of deoxyribonucleic acid base composition in bacterial taxonomy. Antonie van Leeuwenhoek J. Microbiol. Serol. 29:344-358.

9. Goodacre, R., and R. C. W. Berkeley, 1990. Detection of small genotypic changes in Escherichia coli by pyrolysis mass spectrometry. FEMS Microbiol. Lett. 71:133-138.

10. Gordon, R. E., W. C. Haynes, and C. H.-N. Pang. 1973. The genus Bacillus. Agriculture handbook no. 427. U.S. Department of Agriculture, Washington D. C.

11. Gower, J. C. 1971. A general coefficient of similarity and some of its properties. Biometrics 27:857-874.

12. Gürtler, V., V. A. Wilson, and B. C. Mayall. 1991. Classification of medically important clostridia using restriction endonuclease site differences of PCRamplified 16S rDNA. J. Gen. Microbiol. 137:2673-2679.

13. Gutteridge, C. S., L. Vallis, and H. J. H. MacFie. 1985. Numerical methods in the classification of micro-organisms by pyrolysis mass spectrometry, $\mathrm{p}$. 369-401. In M. Goodfellow, D. Jones, and F. G. Priest (ed.), Computer assisted bacterial systematics. Academic Press, New York.

14. Hughes, M. S., R. A. Skuce, L.-A. Beck, and S. D. Neill. 1993, Identification of mycobacteria from animals by restriction enzyme analysis and direct DNA cycle sequencing of polymerase chain reaction-amplified 16S rRNA gene sequences. J. Clin. Microbiol. 31:3216-3222.

15. International Committee on Systematic Bacteriology Subcommittee on the Taxonomy of the Genus Bacillus. 1993. Minutes of the meeting. Int. J. Syst. Bacteriol. 43:185.

16. Krzanowski, W. J. 1988. Principles of multivariate analysis: a user's perspective. Oxford University Press, Oxford.

17. Laguerre, G., M.-R. Allard, F. Revoy, and N. Amarger. 1994. Rapid identification of rhizobia by restriction fragment length polymorphism analysis of PCR-amplified 16S rRNA genes. Appl. Environ. Microbiol. 60:56-63.

18. Logan, N. A., and R. C. W. Berkeley. 1984. Identification of Bacillus strains using the API system. J. Gen. Microbiol. 130:1871-1882.

19. MacFie, H. J. H., C. S. Gutteridge, and J. R. Norris. 1978. Use of canonical variates analysis in differentiation of bacteria by pyrolysis gas-liquid chromatography. J. Gen. Microbiol. 104:67-74.

20. MacGowan, A. P., K. O'Donaghue, J. MacLauchlin, P. M. Bennett, and D. S. Reeves. 1993. Typing of Listeria spp. using random amplified polymorphic DNA (RAPD) analysis. J. Med. Microbiol. 38:322-327.

21. Marmur, J. 1961. A procedure for the isolation of deoxyribonucleic acid from micro-organisms. J. Mol. Biol. 3:208-218.

22. Marmur, J., and P. Doty. 1962. Determination of the base composition of deoxyribonucleic acid from its thermal denaturation temperature. J. Mol. Biol. 5:109-118

23. Nakamura, L. K. 1984. Bacillus amylolyticus sp. nov., nom. rev., Bacillus 
lautus sp. nov., nom. rev., Bacillus pabuli sp. nov., nom. rev., and Bacillus validus sp. nov., nom. rev. Int. J. Syst. Bacteriol. 34:224-226.

24. Nakamura, L. K., and J. Swezey. 1983. Taxonomy of Bacillus circulans Jordan 1890: base composition and reassociation of deoxyribonucleic acid. Int. J. Syst. Bacteriol. 33:46-52.

25. Pichinoty, F., J. B. Waterbury, M. Mandel, and J. Asselineau. 1986. Bacillus gordonae sp. nov., une nouvelle espèce appartenant au second groupe morphologique, dégradant divers composés aromatiques. Ann. Inst. Pasteur/ Microbiol. (Paris) 137A:65-78.

26. Pitcher, D. G., N. A. Saunders, and R. J. Owen. 1989. Rapid extraction of bacterial genomic DNA with guanidium thiocyanate. Lett. Appl. Microbiol. 8:151-156.

27. Pot, B., P. Vandamme, and K. Kersters. 1994. Analysis of electrophoretic whole organism protein fingerprints, p. 493-521. In M. Goodfellow and A. G. O'Donnell (ed.), Chemical methods in prokaryotic systematics. J. Wiley \& Sons, Chichester, United Kingdom.

28. Ralph, D., M. McClelland, J. Welsh, G. Baranton, and P. Perolat. 1993. Leptospira species categorized by arbitrarily primed polymerase chain reaction (PCR) and by mapped restriction polymorphisms in PCR-amplified rRNA genes. J. Bacteriol. 175:973-981.

29. Skerman, V. B. D., V. McGowan, and P. H. A. Sneath (ed.). 1980. Approved lists of bacterial names. Int. J. Syst. Bacteriol. 30:225-420.

30. Smith, N. R., R. E. Gordon, and F. E. Clark. 1952. Aerobic spore-forming bacteria. Agriculture monograph no. 16. U.S. Department of Agriculture, Washington, D.C.

31. Vaneechoutte, M., R. Rossau, P. De Vos, M. Gillis, D. Janssens, N. Paepe, A. De Rouck, T. Fiers, G. Claeys, and K. Kersters. 1992. Rapid identification of bacteria of the Comamonadaceae with amplified ribosomal DNA-restriction analysis (ARDRA). FEMS Microbiol. Lett. 93:227-234.

32. Vauterin, L., and P. Vauterin. 1992. Computer aided objective comparison of electrophoresis patterns for grouping and identification of microorganisms. Eur. Microbiol. 1:37-41.

33. Vauterin, L., P. Yang, B. Hoste, M. Vancanneyt, E. L. Civerolo, J. Swings, and K. Kersters. 1991. Differentiation of Xanthomonas campestris pv. citri strains by sodium dodecyl sulfate-polyacrylamide gel electrophoresis of proteins, fatty acid analysis, and DNA-DNA hybridization. Int. J. Syst. Bacteriol. 41:535-542.

34. Wayne, L. G., D. J. Brenner, R. R. Colwell, P. A. D. Grimont, O. Kandler, M. I. Krichevsky, L. H. Moore, W. E. C. Moore, R. G. E. Murray, E. Stackebrandt, M. P. Starr, and H. G. Trüper. 1987. Report of the Ad Hoc Committee on Reconciliation of Approaches to Bacterial Systematics. Int. J. Syst. Bacteriol. 37:463-464.

35. Willems, A., J. Busse, M. Goor, B. Pot, E. Falsen, E. Jantzen, B. Hoste, M. Gillis, K. Kersters, G. Auling, and J. De Ley. 1989. Hydrogenophaga, a new genus of hydrogen-oxidizing bacteria that includes Hydrogenophaga flava comb. nov. (formerly Pseudomonas flava), Hydrogenophaga palleronii (formerly Pseudomonas palleronii), Hydrogenophaga pseudoflava (formerly Pseudomonas pseudoflava and "Pseudomonas carboxydoflava"), and Hydrogenophaga taeniospiralis (formerly Pseudomonas taeniospiralis). Int. J. Syst. Bacteriol. 39:319-333.

36. Willems, A., M. Gillis, and J. De Ley. 1991. Transfer of Rhodocyclus gelatinosus to Rubrivivax gelatinosus gen. nov., comb. nov., and phylogenetic relationships with Leptothrix, Sphaerotilus natans, Pseudomonas saccharophila, and Alcaligenes latus. Int. J. Syst. Bacteriol. 41:65-73. 